\title{
Kajian Yuridis Dasar Hukum Jaksa Penuntut Umum Melakukan Upaya Hukum Kasasi Terhadap Putusan Bebas (Vrijspraak) Dalam Sistem Peradilan Pidana Indonesia
}

\author{
Heru Drajat Sulistyo \\ Fakultas Hukum, Universitas Soerjo, Jl. Сери Km.3, Ngawi, 63218 \\ E-mail: -
}

\begin{abstract}
This study discusses theoretically normative about the appeal made by the Public Prosecutor on the verdict free (vrijspraak) in the Indonesian Criminal Justice System intended to find solutions to the juridical problems arising from the acquittal. The problem in this study, namely: What is the legal basis for the Public Prosecutor to conduct an appeal against the verdict (vrijspraak). The research method used is a normative legal research method and uses secondary data types, including primary legal materials, secondary legal materials and tertiary legal materials collected through library studies, print media, electronic media. The results of the research study, namely: the legal basis of the Public Prosecutor conducting an appeal against the verdict (vrijspraak) is the Decree of the Minister of Justice of the Republic of Indonesia Number M.14-PW.07.03 of 1983 dated December 10, 1983 concerning Supplementary Guidelines for the Implementation of the Criminal Procedure Code (item 19) . Then the Supreme Court Decree Reg. no: 275 K / Pid / 1983 in the Raden Sonson Natalegawa case was the first decision to be born as jurisprudence for a free verdict after the entry into force of the Criminal Procedure Code. Furthermore, the Constitutional Court Decision Number 114 / PUU-X / 2012 dated March 28, 2013. The existence of the Constitutional Court Decision Number 114 / PUU-X / 2012 dated March 28, 2013, the public must accept the Public Prosecutor is contested with legal action to appeal against the acquittal (vrijspraak).
\end{abstract}

Keywords —: Cassation; Acquittal; Indonesian Criminal Justice System.

\section{PENDAHULUAN}

\section{A. Latar Belakang Masalah}

Pasal 244 UU No.8 Tahun 1981 tentang Hukum Acara Pidana (KUHAP), menyatakan “ Terhadap putusan perkara pidana yang diberikan pada tingkat terakhir oleh pengadilan lain selain daripada Mahkamah Agung, terdakwa atau penuntut umum dapat mengajukan permintaan pemeriksaan kasasi kepada Mahkamah Agung kecuali terhadap putusan beba s".Berdasarkan Pasal 244 KUHAP tersebut, pada kalimat bagian akhir yaitu kecuali terhadap putusan bebas, maka secara yuridis normatif Jaksa Penuntut Umum tidak dapat mengajukan upaya hukum kasasi terhadap putusan bebas (vrijspraak).

Kenyataannya banyak terjadi putusan bebas (vrijspraak) yang diajukan upaya hukum kasasi oleh Jaksa Penuntut Umum ke Mahkamah Agung kemudian di terima dan dikabulkan. Upaya hukum kasasi oleh Jaksa Penuntut Umum terhadap putusan bebas (vrijspraak) ini menimbulkan pro dan kontra dalam masyarkat. Penelitian ini fokus membahas apa yang menjadi dasar hukum Jaksa Penuntut Umum melakukan upaya hukum kasasi terhadap putusan bebas (vrijspraak) dalam Sistem Peradilan Pidana Indonesia.

\section{B. Manfaat Penelitian}

a. Penelitian ini dapat memberikan sumbangan pemikiran tentang dasar hukum yang mengatur Jaksa Penuntut Umum melakukan upaya hukum kasasi terhadap putusan bebas (vrijspraak) dalam sistem peradilan pidana di Indonesia.

b. Penelitian ini diharapkan dapat memperkaya referensi dan literatur dalam dunia kepustakaan tentang kajian mengenai dasar hukum yang mengatur Jaksa Penuntut Umum melakukan upaya hukum kasasi terhadap putusan bebas (vrijspraak).

\section{TINJAUAN PUSTAKA}

\section{A. Sistem Peradilan Pidana}

Menurut Muladi (2002:35), Sistem Peradilan Pidana merupakan suatu jaringan peradilan yang menggunakan hukum pidana materiil, hukum pidana formil maupun hukum pelaksanaan pidana.Selanjutnya Mardjono Reksodiputra (1994:85) menyatakan, Sistem Peradilan Pidana adalah sistem dalam suatu masyarakat untuk menanggulangi masalah kejahatan agar berada dalam batas-batas toleransi masyarakat.

Barda Nawawi Arif (1992:197) berpendapat bahwa Sistem Peradilan Pidana sebagai suatu proses penegakan hukum pidana. Oleh karena itu berhubungan erat dengan perundang-undangan pidana itu sendiri, baik hukum pidana substantif maupun hukum acara pidana. Pada dasarnya, perundang-undangan pidana merupakan penegakan hukum pidana in aostracto yang akan diwujudkan ke adalah penegakan hukum in concrecto. 
Website : http://yustisia.unmermadiun.ac.id/index.php/yustisia

Tujuan dari Sistem Peradilan Pidana sebagai berikut :

Muladi (2002:35), Sistem Peradilan Pidana" harus dilihat sebagai "The network of courts and tribunals which deal with criminal law and its enforceme", Sistem peradilan pidana di dalamnya mengandung gerak sistemik dari subsistem-subsistem pendukungnya ialah kepoiisian, kejaksaan, pengadilan dan lembaga koreksi/pemasyarakatan, yang secara keseluruhan merupakan satu kesatuan yang berusaha mentransformasikan masukan ("input) menjadi keluaran ("output") yang menjadi tujuan sistem peradilan pidana yang terdiri dari :

a. Tujuan jangka pendek berupa resosialisasi pelaku tindak pidana;

b. Tujuan jangka menengah berupa pencegahan kejahatan; dan

c. Tujuan jangka panjang berupa kesejahteraan sosial.

Menurut M. Yahya Harahap (2003:38), bahwa criminal justice system merupakan fungsi gabungan (collection of function) dari legislator, polisi, jaksa, pengadilan dan penjara serta badan yang berkaitan, baik yang ada di lingkungan pemerintah atau di iuamya. Tujuan pokok gabungan fungsi dalam kerangka criminal justice system adalah untuk menegakan, melaksanakan (menjalankan) dan memutus perkara pidana.

Selanjutnya M. Yahaya Harahap (2003:39) menyatakan, Sistem Peradilan Pidana didukung dan dilaksanakan oleh 4 fungsi utama sebagai berikut :

1. Fungsi pembuatan Undang-undang (law making function), fungsi ini dilakukan oleh DPR dan Pemerintah atau badan lain berdasar Delegation Legislation.

2. Fungsi penegakan hukum (law enforcement function), tujuan obyektif fungsi ini ditinjau dari pendekatan tata tertib social (social order).

a. Penegakan hukum secara actual (the actual enforcement) meliputi tindakan : penyelidikan-penyidikan (investigation), penegakan (arrest), penahanan (detention), persidangan (trial) dan penindakan (punishment), pemenjaraan guna memperbaiki tingkah laku individu terpidana (correcting the behavior of individual Effect).

b. Efek Preventif (Preventif Effect).

1) Fungsi pemeriksaan pengadilan (fungtion of adjudication), fungsi ini merupakan sub fungsi dari kerangka penegakan hukum yang dilaksanakan oleh Jaksa Penuntut Umum dan hakim serta pejabat pengadilan yang terkait.

2) Fungsi memperbaiki terpidana (the function of correction), fungsi ini meliputi aktifitas lembaga pemasyarakatan, layanan social terkait dan lembaga kesehatan mental.

\section{B. Upaya Hukum Menurut Undang-Undang Nomor 8 Tahun 1981 tentang Hukum Acara Pidana (Kitab Undang-Undang Hukum Acara Pidana/KUHAP)}

Pengertian upaya hukum dalam Undang-Undang Nomor 8 Tahun 1981 tentang Hukum Acara Pidana (KUHAP) terdapat pada Bab 1 Angka 12 yaitu, upaya hukum adalah hak terdakwa atau penuntut umum untuk tidak menerima putusan pengadilan yang berupa perlawanan atau banding atau kasasi atau hak terpidana untuk mengajukan permohonan peninjauan kembali dalam hal serta menurut cara yang diatur dalam undang-undang ini.

Menurut Andi Hamzah dan Irdan Dahlan (1987:4) menyatakan, upaya hukum dimaksukan merupakan sarana untuk melaksanakan hukum, yaitu hak terpidana atau jaksa penuntut umum untuk tidak menerima penetapan atau putusan pengadilan karena tidak merasa puas dengan penetapan atau putusan pengadilan tersebut.

Secara teoritis dalam Undang-Undang Nomor 8 Tahun 1981 tentang Hukum Acara Pidana (KUHAP), ada dua macam upaya hukum, yaitu, upaya hukum biasa, terdiri dari perlawanan, banding, kasasi dan upaya hukum luar biasa, terdiri dari kasasi demi kepentingan hukum dan peninjauan kembali putusan pengadilan yang telah memperoleh kekuatan hukum tetap.

\section{Upaya Hukum Kasasi Menurut Undang-Undang Nomor 8 Tahun 1981 tentang Hukum Acara Pidana (Kitab Undang - Undang Hukum Acara Pidana/KUHAP)}

Tidak ada definisi upaya hukum kasasi dalam Undang-Undang Nomor 8 Tahun 1981 tentang Hukum Acara Pidana. Pemahaman upaya hukum kasasi dapat dilihat pada Pasal 244 Undang-Undang Nomor 8 Tahun 1981 tentang Hukum Acara Pidana (KUHAP), yaitu terhadap perkara pidana yang diberikan pada tingkat terakhir oleh pengadilan lain selain daripada Mahkamah Agung, terdakwa atau penuntut umum dapat mengajukan permintaan pemeriksaan kasasi kepada Mahkamah Agung kecuali terhadap putusan bebas.

Menurut Harun M. Husein (1992:48), upaya hukum kasasi itu adalah : hak terdakwa atau penuntut umum untuk tidak menerima putusan pengadilan pada tingkat terakhir, dengan cara mengajukan permohonan kepada Mahkamah Agung guna membatalkan putusan pengadilan tersebut, dengan alasan (secara aiternam/kumuiatif) bahwa dalam putusan yang dimintakan kasasi tersebut, peraturan hukum tidak diterapkan atau dsterapkan tidak sebagaimana mestinya, cara mengadili tidak dilaksanakan menurut ketentuan undang-undang, pengadilan telah melampaui batas wewenangnya.

Selanjutnya R. Soesilo (1992:138), kasasi itu jalan hukum untuk melawan keputusan-keputusan hakim yaitu keputusankeputusan yang tidak dapat dimohonkan banding baik oleh karena tidak diperbolehkan oleh undang-undang maupun karena kesempatan banding itu telah dipergunakan. 
Alasan upaya hukum kasasi telah diatur dalam Pasal 253 ayat (1) Undang-Undang Nomor 8 Tahun 1981 tentang Hukum Acara Pidana sebagai berikut :

a. Apakah benar suatu peraturan hukum tidak diterapkan atau diterapkan tidak sebagaimana mestinya;

b. Apakah benar cara mengadili tidak dilaksanakan menurut ketentuan undang-undang.

c. Apakah benar pengadilan telah melampaui batas wewenangnya.

Dengan demikian alasan-alasan pengajuan upaya hukum kasasi ada tiga hal, yaitu tentang penerapan hukumnya, tentang cara mengadili dan tentang wewenang pengadilan.

Undang-Undang Nomor 8 Tahun 1981 tentang Hukum Acara Pidana (KUHAP) mengatur tata cara pengajuan upaya hukum kasasi, sebagai berikut :

a. Pemohonan kasasi disampaikan oleh Permohon kepada Panitera Pengadilan yang memutus perkaranya dalam tingkat pertama, dalam waktu 14 (empat betas) hari sesudah putusan pengadilan yang dimintakan kasasi itu diberitahukan kepada terdakwa.(Pasal 245 ayat (1) KUHAP).

b. Permintaan tersebut oleh panitera ditulis dalam sebuah surat keterangan yang ditandatangani oteh Panitera serta pemohon, dan dicatat dalam daftar yang dilampirkan pada berkas perkara (Pasal 245 ayat (2) KUHAP).

c. Dalam hal pengadilan negeri menerima permohonan kasasi, baik yang oleh Penuntut Umum dan terdakwa sekaligus, maka Panitera wajib memberitahukan permintaan dari pihak yang satu kepada pihak yang lain (Pasal 245 ayat (3) KUHAPl)

d. Apabila tenggang waktu 14 hari sebagaimana dimaksud dalam Pasal 245 ayat (1) telah lewat tanpa diajukan permohonan kasasi oleh yang bersangkutan. Maka yang bersangkutan dianggap menerima putusan (Pasal 246 ayat (1) KUHAP).

e. Apabila dalam tenggang waktu sebagaimana dimaksud Pasal 246 ayat (1), pemohon teriambat mengajukan permohonan kasasi maka hak untuk permohonan kasasi itu gugur (Pasal 246 ayat (2 )KUHAP).

f. Selama perkara permohonan kasasi beium diputus oleh Mahkamah Agung, permohonan kasasi itu dapat dicabut sewaktuwaktu dan apabila sudah dicabut, permohonan kasasi dalam perkara itu tidak dapat diajukan lagi (Pasal 247 ayat (1) KUHAP).

g. Jika pencabutan dilakukan sebelum berkas perkara dikirirn ke Mahkamah Agung, berkas tersebut tidak jadi dikirim (Pasal 247 ayat (2) KUHAP)

h. Apabila perkara telah mulai diperiksa, akan tetapi belum diputus sedangkan sementara itu pemohon mencabut permohonan kasasinya, maka pemohon dibebani membayar biaya perkara yang telah dikeluarkan oleh Mahkamah Agung hingga saat pencabutannya (Pasal 247 ayat (3) KUHAP).

i. Permohonan kasasi hanya dapat dilakukan satu kali (Pasal 247 ayat (4) KUHAP.

j. Pemohon kasasi wajib membuat memori kasasi yang berisi alasan-alasan permohonan kasasinya dan dalam waktu empat belas hari setelah mengajukan permohonan tersebut, harus sudah menyerahkan kepada panitera, yang untuk itu ia memberikan surat tanda terima (Pasal 248 ayat (1) KUHAP).

k. Apabila dalam tenggang waktu sebagaimana dimaksud dalam ayat (1) Pasal 248 KUHAP pemohon terlambat menyerahkan memori kasasi maka hak untuk mengajukan permohonan kasasi gugur (Pasal 248 ayat (4) KUHAP).

Putusan kasasi yang dijatuhkan Mahkamah Agung diatur Pasal 254 KUHAP, yaitu, dalam hal Mahkamah Agung menerima permohonan kasasi karena telah memenuhi ketentuan sebagaimana dimaksud dalam Pasal 245, 246 dan Pasal 247 KUHAP, mengenai hukumnya Mahkamah Agung dapat memutus menolak atau mengabulkan permohonan kasasi.

Pendapat Mohammad Taufik Makarao dan Suhasril (2004:223-226) mengenai Putusan Mahkamah Agung yaitu :

a. Putusan yang menyatakan kasasi tidak dapat diterima, yaitu apabila permohonan kasasi tidak memenuhi syarat formii, antara lain;

- Permohonan kasasi terlambat diajukan dari tenggang waktu 14 hari;

- Tidak mengajukan memori kasasi

- Memori kasasi terlambat disampaikan.

b. Putusan yang menolak permohonan kasasi, yaitu permohonan sampai menguji mengenai hukumnya, tetapi putusan yang dikasasi ternyata tidak mengandung kesalahan dalam penerapan hukum sebagaimana mestinya juga tidak terdapat cara mengadili yang bertentangan dengan ketentuan undang-undang atau dalam mengadili perkara tersebut pengadilan yang bersangkutan tidak melampaui batas wewenngnya. Dengan kata lain, putusan pengadilan yang dikasasi tidak terdapat cacat dan kesalahan yang bertentangn dengan pasal 233 ayat 1 KUHAP)

c. Putusan yang mengabulkan permohonan kasasi. Putusan ini berarti putusan pengadilan yang dikasasi dibatalkan oleh Mahkamah Agung dengan alasan putusan tersebut mengandung pelanggaran terhadap ketentuan pasal 253 ayat (1), yaitu meliputi berikut ini :

1. Peraturan hukum tidak diterapkan sebagaimana mestinya.

2. Cara mengadili tidak dilaksanakan menurut ketentuan undang-undang.

\section{Jenis-Jenis Putusan Dalam Perkara Pidana}

Definisi putusan pengadilan dalam KUHAP terdapat pada Pasal 1 angka 11 KUHAP, yaitu : Putusan pengadilan adalah pemyataan hakim yang diucapkan dalam sidang pengadilan yang terbuka, yang dapat berupa pemidanaan atau bebas atau lepas dari segala tuntutan hukum dalam hal serta menurut cara yang diatur dalam Undang-undang ini. 
Berdasarkan ketentuan Pasal 1 angka 11 KUHAP tersebut terdapat tiga bentuk putusan pengadilan dalam perkara pidana menurut KUHAP, yakni: putusan bebas dari segala tuduhan hukum, putusan lepas dari segala tuntutan hukum dan putusan yang mengandung pemidanaan, yang akan diuraikan secara ringkas sebagai berikut :

a. Putusan Bebas (vrijsprssk)

Putusan bebas (vrijspraak), diatur Pasal 191 ayat (1) KUHAP, yaitu : Jika pengadilan berpendapat bahwa dari hasil pemeriksaan di sidang, kesalahan terdakwa atas perbuatan yang didakwakan kepadanya tidak terbukti secara sah dan meyakinkan maka terdakwa diputus bebas.

Menurut M. Yahya Harahap (1985:965), mencermati esensi Pasal 191 ayat (1) KUHAP, maka secara yuridis putusan bebas merupakan putusan yang dinilai oleh Majelis Hakim sebagai berikut:

1. Tidak memenuhi asas pembuktian menurut Undang-Undang secara negatif. Dari hasil pembuktian yang diperoleh di persidangan, tidak cukup membuktikan kesaianan terdakwa dan sekaligus pula kesalahan terdakwa yang tidak cukup bukti tadi, tidak diyakini oleh hakim.

2. Atau tidak memenuhi asas batas minimum pembuktian, kesalahn yang didakwakan kepada terdakwa hanya didukung oleh satu alat bukti saja, sedang menurut ketentuan pasal 183 KUHAP, agar cukup membuktikan kesalahan seorang terdakwa, harus dibuktikan dengan sekurang-kurangnya dua alat bukti yang sah

Selanjutnya M. Yahya Harahap berpendapat, (1985:967), Dengan bertitik tolak dan dua asas yang diatur dalam Pasal 183 KUHAP, apabila dihubungkan dengan Pasal 191 ayat (1) KUHAP, putusan bebas pada umumnya didasarkan pada penilaian dan pendapat hakim, yakni:

1. Kesalahan yang didakwakan kepada terdakwa sama sekali tidak terbukti, semua alat bukti yang diajukan di persidangan baik berupa keterangan saksi, keterangan ahli, surat dan petunjuk maupun keterangan terdakwa, tidak dapat membuktikan kesalahan yang didakwakan, berarti perbuatan yang didakwakan tidak terbukti secara sah dan menyakinkan.

2. Atau secara nyata hakim menilai, pembuktian kesalahan yang didakwakan tidak memenuhi ketentuan batas minimum pembuktian. Misalnya, alat bukti yang diajukan di persidangan hanya terdiri dan seorang saksi saja

3. Atas putusan bebas tersebut bisa juga didasarkan atas penilaian, kesalahan yang terbukti itu tidak didukung oleh Keyakinan hakim.

Vrijspraak adalah putusan hakim yang mengandung pembebasan terdakwa, karena penstiwa-penstiwa yang disebutkan dalam surat dakwaan setelah diadakan perubahan atau penambahan selama persidangan, bila ada sebagian, atau seluruh dinyatakan oleh hakim yang memeriksa dan mengadiii perkara yang bersangkutan dianggap tidak terbukti. (Djoko Prakoso, 1985: 270)

Selanjutnya pendapat Harun M. Husein, (1992:108) menyatakan, sesuai dengan rumusan pengertian bebas dalam Pasal 191 ayat 1 KUHAP, maka dapat kita definisikan bahwa yang dimaksud dengan putusan bebas, ialah putusan pengadilan yang membebaskan terdakwa dari dakwaan, karena menurut pendapat pengadilan terdakwa tidak terbukti dengan sah dan meyakinkan bersalah melakukan tindak pidana yang didakwakan kepadanya.

Pasal 183 KUHAP menyatakan, Hakim tidak boleh menjatuhkan pidana kepada seseorang kecuali apabila dengan sekurang-kurangnya dua alat bukti yang sah ia memperoleh keyakinan bahwa suatu tindak pidana benar-benar terjadi dan bahwa terdakwalah yang bersalah melakukannya.

Jadi putusan bebas (vrijspraak), secara normatif karena tidak memenuhi dua alat bukti yang sah.

Alat bukti yang sah diatur Pasal 184 ayat (1) KUHAP, yaitu :

Pasal 184 ayat (1) menyatakan :

Alat bukti yang sah adalah:

a. Keterangan saksi;

b. Keterangan ahli,

c. Surat;

d. Petunjuk;

e. Keterangan terdakwa.

b. Putusan lepas dari segala tuntutan hukum (ontslag van alle rechtsvervolging)

Putusan lepas dari segala tuntutan hukum (ontslag van alle rechtsvervolging) secara yuridis diatur dalam Pasal 191 ayat (2) KUHAP, yaitu : Jika pengadilan berpendapat bahwa perbuatan yang didakwakan kepada terdakwa terbukti, tetapi perbuatan itu tidak merupakan suatu tindak pidana maka terdakwa diputus lepas dari segala tuntutan hukum.

Menurut Djoko Prakoso (1985:272-273) Alasan-alasan dijatuhkannya putusan lepas dari segala tuntutan hukum :

1. Karena penstiwa-peristiwa yang dalam surat dakwaan yang didakwakan kepada terdakwa adalah terbukti, akan tetapi yang terang terbukti itu tidak merupakan suatu kejahatan atau peianggaran maka terdakwa dalam putusan hakim harus dilepas dari segala tuntutan hukum.

2. Apabila ada keadaan istimewa yang mengakibatkan bahwa terdakwa tidak dapat dijatuhi suatu hukuman pidana menurut beberapa pasal dari Kitab Undang-undang Hukum Pidana (KUHP) atau adanya alasan-alasan pemaaf, yaitu seperti yang disebutkan dalam : 
a. Pasal 44 KUHP, kalau perbuatan terdakwa tidak dapat dipertanggungjawabkan kepadanya oleh karena penyakit jiwa;

b. pasal 48 KUHP, kalau terdakwa melakukan perbuatan terdorong oleh keadaan memaksa (overmacht);

c. pasal 49 KUHP, kalau terdakwa meiakukan oerbuatan berada dalam keadaan diserang oleh orang lain dan hams membela diri (noordeer);

d. pasal $50 \mathrm{KUHP}$, kaiau terdakwa melakukan perbuatan untuk menjalankan suatu peraturan dalam undang-undang atau;

e. pasal $51 \mathrm{KUHP}$, kalau terdakwa melakukan perbuatan untuk memenuhi suatu perintah yang diberikan secara sah o!eh seorang pejabat yang berkuasa dalam hal itu.

c. Putusan Pemidanaan

Putusan pemidanaan diatur dalam Pasal 191 ayat (3) KUHAP, yaitu : Jika pengadilan berpendapat bahwa terdakwa bersalah melakukan tindak pidana yang didakwakan kepadanya, maka pengadilan menjatuhkan pidana.

Pasal10 KUHP mengatur jenis-jenis pemidaan, yaitu :

1. Hukuman Pokok, terdiri dari:
a. Hukuman mati
b. Hukuman penjara
c. Hukuman kurungan dan
d. Hukuman denda

2. Hukuman tambahan, terdiri dari :

a. Pencabutan beberapa hak tertentu

b. Perampasan barang tertentu

c. Pengumuman keputusan hakim

\section{III.METODE PENELITIAN}

Metodologi adalah pengetahuan tentang berbagai cara kerja yang disesuaikan dengan objek studi ilmu yang bersangkutan. Dengan kata lain metodelogi itu menjelaskan tata cara dan langkah yang akan ditempuh untuk mencapai tujuan penelitian (Koentjaraningrat, 1981:61).

Menurut Setiono (2005:3) metode adalah alat untuk mencari jawab. Jadi menggunakan suatu metode (alat) harus mengetahui dulu apa yang dicari.

Penelitian hukum merupakan suatu kegiatan ilmiah yang didasarkan pada metode,sistematika, dan pemikiran tertentu yang bertujuan untuk mempelajari satu atau beberapa gejala hukum tertentu dengan jalan menganalisanya (Soerjono Soekanto, 1986: 42-43).

Adapun metode penelitian sebagai berikut:

a. Jenis Penelitian

Penelitian hukum normatif adalah penelitian hukum yang dilakukan dengan cara meneliti bahan pustaka atau data sekunder belaka (Soerjono Soekamto dan Sri Mamudji (2004:13)

Penelitian ini termasuk jenis penelitian hukum normatif karena dilakukan dengan cara meneliti bahan pustaka atau data sekunder.

b. Pendekatan Masalah

Menurut Peter Mahmud Marzuki (2008 : 93) Pendekatan-pendakatan yang digunakan di dalam penelitian hukum diantaranya: pendekatan undang-undang (statute approache), pendekatan kasus (case approach), pendekatan historis (historical approach), pendekatan komparatif (comparative approach), dan pendekatan konseptual (conceptual approach). Penelitian ini menggunakan beberapa pendekatan antara lain : pendekatan perundang-undangan, pendekatan historis, pendekatan konseptual dan pendekatan komparatif. Pendekatan Perundang-undangan dengan cara menelaah semua UndangUndang dan regulasi yang berhubungan dengan isu hukum dalam penelitian ini. Pendekatan historis dengan cara menelaah latar belakang dan perkembangan pengaturan mengenai isu hukum yang dihadapi. Pendekatan konseptual dilakukan dengan cara mempelajari doktrin-doktrin yang berkembang didalam ilmu hukum.

Menurut Peter Mahmud marzuki (2008:93-94), dengan mempelajari pandangan-pandangan dan doktrin-doktrin yang ada, peneliti akan menemukan ide-ide yang melahirkan pengertian-pengertian hukum, konsep-konsep hukum, dan asas-asas hukum yang relevan dengan isu hukum yang dihadapi. Pemahaman akan pandangan-pandangan dalam ilmu hukum tersebut merupakan sandaran bagi peneliti dalam membangun suatu argumentasi hukum dalam menjawab isu yang dihadapi.

1. Pengumpulan Data

Pengumpulan data dilakukan melalui studi pustaka, dokumen dan arsip.

2. Sumber Data

Penelitian menggunakan Sumber data sekunder, terdiri :

a. Bahan hukum primer, berupa peraturan perundang-undangan yang ada hubungannya dengan upaya hukum kasasi.

b. Bahan hukum sekunder, seperti buku-buku. 
Website : http://yustisia.unmermadiun.ac.id/index.php/yustisia

3. Analisa Data

Bahan-bahan hukum yang telah diperoleh, baik bahan hukum primer maupun bahan hukum sekunder merupakan data kualitatif, yang kemudian diolah dan dianalisis secara deskriptif sesuai dengan permasalahan yang dibahas. Sehingga penelitian ini bersifat deskriptif analisis.

\section{IV.PEMBAHASAN HASIL PENELITIAN}

Dasar Hukum Jaksa Penuntut Umum Melakukan Upaya Hukum Kasasi Terhadap Putusan Bebas (Vrijspraak).

\section{A. Yurisprudensi sebagai dasar hukum Jaksa Penuntut Umum mengajukan upaya hukum kasasi terhadap putusan bebas (vrijsprak).}

Putusan bebas (vrijspraak) selalu menjadi perhatian masyarakat, terlebih lagi untuk kasus-kasus besar yang berskala nasional, maka putusan bebas akan mengundang reaksi pro dan kontra dalam masyarakat.

Menurut Pasal 244 KUHAP terhadap putusan bebas (vrijspraak), Jaksa Penuntut Umum tidak dapat mengajukan upaya hukum kasasi kepada Mahkamah Agung. Pasal 244 KUHAP, menyatakan, Terhadap putusan perkara pidana yang diberikan pada tingkat terakhir oleh pengadilan lain selain daripada Mankamah Agung, terdakwa atau penuntut umum dapat mengajukan permintaan pemeriksaan kasasi kepada Mahkamah Agung kecuali terhadap putusan bebas.

Terjadi perkembangan dalam praktek peradilan pidana Indonesia, yakni terhadap ketentuan Pasal 244 KUHAP tersebut, Jaksa Penuntut Umum dapat melakukan upaya hukum kasasi terhadap putusan bebas (vrijspraak) kepada Mahkamah Agung. Hal ini merupakan suatu langkah Jaksa Penuntut Umum untuk memenuhi rasa ketidak adilan masyarakat menurut persepsi publik (masyarakat) terhadap putusan bebas (vrijspraak).

Menurut Harun M Husein (1992:119), Ketentuan terhadap putusan bebas yang secara langsung dapat dimintakan kasasi Kepada Mahkamah Agung sebagai berikut :

1. Surat Keputusan Menteri Kehakiman RI Nomor: M. 01-PW. 07. 03 Tahun 1982 tanggal 4 Pebruari 1982 tentang Pedoman Pelaksanaan KUHAP.

2. Lampiran Keputusan Menteri Kehakiman RI Nomor M. 14-PW. 07.03 Tahun 1983 tanggal 10 Desember 1983.

3. Yurisdensi Mahkamah Agung.

Keputusan Menteri Kehakiman RI Nomor: M. 01-PW. 07. 031982 tanggal 4 Pebruari 1982 tentang Pedoman Pelaksanaan KUHAP, menyatakan : Mengingat bahwa mengenai masalah "salah atau tidak tepatnya penerpan hukum" merupakan alasan yang dapat dipakai dalam mengajukan permohonan kasasi, maka haruslah diartikan bahwa terhadap semua putusan lepas dari segala tuntutan hukum tidak dapat diajukan permintaan banding, melainkan hanya boleh dimohonkan kasasi.

Esensi dari butir 19 Keputusan Menteri Kehakiman RI Nomor : M.14-PW.07.03 Tahun 1983 tanggal 10 Desember 1983 yaitu : terhadap putusan bebas tidak dapat dimintakan banding; tetapi berdasarkan situasi dan kondisi, demi hukum, keadilan dan kebenaran terhadap putusan bebas dapat dimintakan kasasi. Hal ini akan didasarkan pada yurisprudensi.(Departemen Kehakiman Republik Indonesia (II), Pedoman Pelaksanaan KUHAP, 1982:324).

Berdasarkan ketentuan Keputusan Menteri Kehakiman RI Nomor: M. 14-PW. 07. 03. Tahun 1983 tersebut maka terhadap putusan bebas, Jaksa Penuntut Umum dapat mengajukan kasasi kepada Mahkamah Agung tanpa terlebih dahulu melalui upaya hukum banding. Keputusan Menteri Kehakiman ini menjadi titik awal lahirnya yurisprudensi yang menyangkut putusan bebas.

Untuk pertama kalinya dalam lembaran sejarah peradilan Indonesia sejak diberlakukannya KUHAP, Jaksa Penuntut Umum melakukan upaya hukum kasasi kasus Raden Sonson Natalegawa atas putusan bebas. Selanjutnya Mahkamah Agung mengabulkan permohonan Jaksa Penuntut Umum atas permohonan kasasi kasus Raden Sonson Natalegawa dengan Putusan Mahkamah Agung Rl Regno: 275 K/Pid/1983 tanggal 15 Desember Tahun 1983.

Yuriprudensi Mahkamah Agung Rl Regno: 275 K/Pid/1983 tanggal 15 Desember Tahun 1983 tersebut menjadi acuan dan dasar pembenar secara yuridis normatif bagi Jaksa Penuntut Umum untuk mengajukan upaya hukum kasasi terhadap putusan bebas (vrijspraak) di tingkat pemeriksaan pengadilan negeri.

Putusan Mahkamah Agung Rl Regno: 275 K/Pid/1983 tanggal 15 Desember Tahun 1983 inilah yang menjadi yurisprudensi Jaksa Penuntut Umum untuk melakukan upaya hukum kasasi terhadap putusan bebas (vrijspraak).

Menurut Leden Marpaung (1992:446-447), Putusan Mahkamah Agung Rl Regno: 275 K/Pid/1983 tanggal 15 Desember Tahun 1983 tersebut melahirkan dua yurisprudensi yang isinya, yaitu :

1. Putusan Pengadilan yang membebaskan terdakwa dapat diajukan kasasi. Mahkamah Agung (MA) dalam putusan tersebut di atas, pada pertimbangan-pertimbangannya antara lain mencantumkan sebagai berikut:

“..............sesuai dengan yurisprudensi yang ada apabila ternyata putusan pengadilan yang membebaskan terdakwa itu merupakan pembebasan yang murni sifatnya, maka sesuai dengan ketentuan Pasal 244 KUHAP, permohonan kasasi tersebut harus dinyatakan tidak dapat diterima. Sebaliknya, apabila pembebasan itu didasarkan pada penafsiran yang keliru terhadap sebutan tindak pidana yang disebutkan dalam surat dakwaan dan bukan didasarkan pada tidak terbuktinya unsur-unsur perbuatan yang didakwakan atau apabila dalam menjatuhkan putusan itu pengadilan telah melampaui batas wewenang dalam arti bukan saja wewenang yang menyangkut kompetensi absolut atau relatif, tetapi juga dalam hal apabila ada unsur non yuridis yang turut dipertimbangkan dalam putusan itu, hal mana dalam melaksanakan wewenang pengawasannya 
meskipun hal itu tidak diajukan sebagai keberatan kasasi oleh Jaksa. Mahkamah Agung wajib menelitinya bahwa pembebasan itu bukan merupakan pembebasan yang murni, Mahkamah Agung harus menenma permohonan kasasi tersebut.

2. Penafsiran "melawan hukum", mengenai hal ini Mahkamah Agung dalam mempertimbangkan, antara lain mencantumkan:

"Suatu perbuatan dapat dianggap sebagai perbuatan melawan hukum, tidak semata-mata diukur dari segi perbuatan pelanggaran terhadap peraturan perundang-undangan yang diancam dengan hukum pidana tertulis maupun asas-asas yang bersifat umum, tapi juga menurut kepatutan dalam kehidupan dalam masyarakat perbuatan itu menurut penilaian masyarakat merupakan perbuatan tercela."

Pendapat Harun M. Husein (1992:120), tentang yurisprudensi Mahkamah Agung mengenai putusan bebas :

"Pada hemat kami Mahkamah Agung tidaklah melahirkan yurisprudensi yang bertentangan dengan undang-undang, bahkan Mahkamah Agung berusaha meluruskan penerapan hukum yang dilakukan oleh pengadilan, agar penerapan hukum tersebut benar-benar sesuai dengan arti dan makna yang terkandung di dalamnya. Dengan cara ini, Mahkamah Agung berusaha untuk menyesuaikan pelaksanaan ketentuan undang-undang dengan aspirasi hukum dan keadilan yang hidup dan berkembang dalam masyarakat.

Sebab larangan kasasi terhadap putusan bebas, dirasakan terlalu idealistik dan belum sesuai dengan situasi dan kondisi masyarakat kita, oleh karena itu demi hukum, kebenaran dan keadilan, Mahkamah Agung membenarkan pengajuan upaya hukum kasasi terhadap putusan bebas."

\section{B. Putusan Mahkamah Konstitusi Nomor 114/PUU-X/2012 sebagai dasar hukum Jaksa Penuntut Umum mengajukan upaya hukum kasasi terhadap putusan bebas (vrijsprak)}

Perkara mahkamah Konstitusi Nomor 114/PUU-X/2012 adalah perkara pengujian Pasal 244 Undang-Undang Nomor 8 Tahun 1981 tentang Hukum Acara Pidana (Kitab Undang-Undang Hukum Acara Pidana) terhadap Undang-Undang Dasar Negara Republik Indonesia Tahun 1945, selengkapnya berbunyi :" Terhadap putusan perkara pidana yang diberikan pada tingkat terakhir oleh pengadilan lain selain dari Mahkamah Agung, terdakwa atau Penuntut Umum dapat mengajukan permintaan pemeriksaan kasasi kepada Mahkamah Agung kecuali terhadap putusan bebas, terhadap :

- Pasal 1 ayat (3) UUD 1945 yang berbunyi "Negara Indonesia adalah negara Hukum “.

- Pasal 27 ayat (1) UUD 1945 yang berbunyi "Segala warga Negara bersamaan kedudukannnya didalam hukum dan pemerintahan dan wajib menjunjung hukum dan pemerintahan itu dengan tidak ada kecualinya".

- Pasal 28D ayat (1) UUD 1945, yang berbunyi "Setiap orang berhak atas pengakuan, jaminan, perlindungan dan kepastian hukum yang adil serta perlakuan yang sama didepan hukum “.

diajukan oleh :

Nama $\quad: \quad$ Dr. H. Idrus, M. Kes.

Pekerjaan : Pensiunan Pegawai Negeri Sipil

Alamat : Jalan Ahmad Yani, Nomor 10, Lubuksikaping, Sumatera Barat.

Pemohon (Dr. H. Idrus, M. Kes.) sebelumnya telah divonis bebas oleh Pengadilan Negeri Lubuksikaping dengan register perkara nomor 55/PID/2007/PN.Lbs. tanggal 18 Juni 2008. Selanjutnya Jaksa Penuntut Umum (JPU) mengajukan upaya hukum kasasi berdasarkan Pasal 244 KUHAP. Pertimbangan Hukum Mahkamah Konstitusi. Pertimbangan hukum dari Hakim MK terbelah dua (dissenting opnion) dalam menguji konstitusionalitas Pasal 244 KUHAP.

Hakim Konstitusi Harjono mempunyai pendapat berbeda (dissenting opnion) yang intinya, menurut Hakim Konstitusi Harjono Pasal 244 KUHAP tidak bertentangan dengan UUD 1945. Kutipan sebagian pendapat Hakim Konstitusi Harjono “...Dengan dihilangkannya frasa "kecuali putusan bebas" Pasal 244 KUHAP maka secara fundamental telah merobohkan sistem KUHAP, yang implikasinya akan memandulkan banyak pasal KUHAP yang lain, padahal penghilangan tersebut tidak ada dasar konstitusionalnya. Praktik bukanlah rujukan untuk menyatakan sebuah undang-undang bertentangan dengan Undang Undang Dasar dan justru pengujian undang-undang seringkali dimaksudkan untuk mengoreksi apakah praktik yang berlaku telah sesuai dengan konstitusi, oleh karenanya tidak jarang Mahkamah memutuskan dengan konstitusional bersyarat (conditionally constitutional) untuk mengoreksi praktik yang tidak benar tersebut dan tidak sebaliknya".

Mayoritas hakim konstitusi berpendapat frasa "kecuali terhadap putusan bebas" dalam Pasal 244 KUHAP bertentangan dengan konstitusi.

Putusan Mahkamah Konstitusi terhadap pengujian konstitusionalitas Pasal 244 KUHAP sebagai upaya mewujudkan kepastian hukum dalam pengajuan kasasi atas putusan bebas (vrijspraak) oleh JPU telah mendapat pertimbangan hukum yang sangat mendasar. Hal ini dapat dilihat dari pendapat Mahkamah Konstitusi pada bagian (3.13.1), yaitu "Bahwa Pasal 24 ayat (2) UUD 1945 menentukan, "Kekuasaan kehakiman dilakukan oleh sebuah Mahkamah Agung dan badan peradilan yang berada di bawahnya dalam lingkungan peradilan umum, lingkungan peradilan agama, lingkungan peradilan militer, lingkungan peradilan tata usaha negara, dan oleh sebuah Mahkamah Konstitusi”. Dari ketentuan tersebut jelas bahwa Mahkamah Agung adalah pengadilan negara tertinggi dari keempat lingkungan peradilan yang berada di bawahnya. Sebagai pengadilan negara tertinggi dari keempat lingkungan peradilan tersebut, menjadi mutlak bahwa Mahkamah Agung memiliki kewenangan mengadili pada tingkat kasasi terhadap putusan dari keempat lingkungan peradilan yang berada di bawahnya. Sebagai pengadilan negara tertinggi dari keempat lingkungan peradilan tersebut, menjadi mutlak bahwa Mahkamah Agung memiliki kewenangan mengadili pada tingkat kasasi terhadap putusan dari keempat lingkungan peradilan yang berada di bawahnya. Meskipun demikian, pembentuk undang-undang telah membatasi kewenangan tersebut dengan menentukan antara lain dalam Pasal 67 
Website : http://yustisia.unmermadiun.ac.id/index.php/yustisia

KUHAP yang menyatakan, "Terdakwa atau penuntut umum berhak untuk minta banding terhadap putusan pengadilan tingkat pertama kecuali terhadap putusan bebas, lepas dari segala tuntutan hukum yang menyangkut masalah kurang tepatnya penerapan hukum dan putusan pengadilan dalam acara cepat”, dan Pasal 244 yang menegaskan, " Terhadap putusan perkara pidana yang diberikan pada tingkat terakhir oleh pengadilan lain selain daripada Mahkamah Agung, terdakwa atau penuntut umum dapat mengajukan permintaan pemeriksaan kasasi kepada Mahkamah Agung kecuali terhadap putusan bebas". Apabila Pasal 67 KUHAP menentukan pengecualian untuk memohon pemeriksaan banding terhadap putusan tingkat pertama yang menyatakan bebas, lepas dari segala tuntutan hukum yang menyangkut masalah kurang tepatnya penerapan hokum dan putusan pengadilan dalam acara cepat, maka Pasal 244 KUHAP mengecualikan permohonan pemeriksaan kasasi terhadap putusan bebas. Kedua ketentuan tersebut sama sekali tidak memberikan upaya hukum biasa terhadap putusan bebas, yang berarti fungsi Mahkamah Agung sebagai pengadilan kasasi terhadap putusan bebas yang dijatuhkan oleh pengadilan yang ada di bawahnya sama sekali ditiadakan".

Selajutnya pertimbangan Mahkamah pada bagian (3.13.2) menyatakan "Bahwa tanpa bermaksud melakukan penilaian atas putusan-putusan Mahkamah Agung, kenyataan selama ini menunjukkan bahwa terhadap beberapa putusan bebas yang dijatuhkan oleh pengadilan yang berada di bawah Mahkamah Agung, memang tidak diajukan permohonan banding [vide Pasal 67 KUHAP], akan tetapi diajukan permohonan kasasi dan Mahkamah Agung mengadilinya. Padahal, menurut ketentuan Pasal 244 KUHAP terhadap putusan bebas tidak boleh dilakukan upaya hukum kasasi. Hal itu mengakibatkan terjadinya ketidakpastian hukum dalam praktik karena terjadinya kontradiksi dalam implementasi pasal tersebut. Di satu pihak pasal tersebut melarang upaya hukum kasasi, namun di lain pihak Mahkamah Agung dalam praktiknya menerima dan mengadili permohonan kasasi terhadap putusan bebas yang dijatuhkan oleh pengadilan di bawahnya. Oleh karena itu, untuk menjamin kepastian hukum yang adil dan perlakuan yang sama di hadapan hukum, Mahkamah perlu menentukan konstitusionalitas Pasal 244 KUHAP khususnya frasa "kecuali terhadap putusan bebas".

Selanjutnya amar putusan Mahkamah Konstitusi Nomor 114/PUU-X/2012 sebagai berikut :

\section{AMAR PUTUSAN, \\ Mengadili,}

Menyatakan

1. Mengabulkan permohonan Pemohon untuk sebagian;

1.1 Menyatakan frasa, "kecuali terhadap putusan bebas" dalam Pasal 244 Undang Undang Nomor 8 Tahun 1981 tentang Hukum Acara Pidana (Lembaran Negara Republik Indonesia Tahun 1981 Nomor 76, Tambahan Lembaran Negara Republik Indonesia Nomor 3209) bertentangan dengan Undang-Undang Dasar Negara Republik Indonesia Tahun 1945;

1.2 Menyatakan frasa, “kecuali terhadap putusan bebas” dalam Pasal 244 Undang-Undang Nomor 8 Tahun 1981 tentang Hukum Acara Pidana (Lembaran Negara Republik Indonesia Tahun 1981 Nomor 76, Tambahan Lembaran Negara Republik Indonesia Nomor 3209) tidak mempunyai kekuatan hukum mengikat;

2. Memerintahkan pemuatan putusan ini dalam Berita Negara Republik Indonesia sebagaimana mestinya;

3. Menolak permohonan Pemohon untuk selain dan selebihnya;

Dengan adanya putusan Mahkamah Konstitusi Nomor 114/PUU-X/2012 tersebut Jaksa Penuntut Umum telah memperoleh kepastian hukum dalam mengajukan kasasi atas putusan bebas (vrijspraak).

\section{KESIMPULAN DAN SARAN}

\section{A. Kesimpulan}

Dasar hukum Jaksa Penuntut Umum melakukan upaya hukum kasasi terhadap putusan bebas (vrijspraak) adalah Putusan Mahkamah Konstitusi Nomor 114/PUU-X/2012 tanggal 28 Maret 2013.

\section{B. Saran-Saran}

Dengan adanya Putusan Mahkamah Konstitusi Nomor 114/PUU-X/2012 tanggal 28 Maret 2013 maka masyarakat harus menerima Jaksa Penuntut Umum diperbolekan melakukan upaya hukum kasasi terhadap putusan bebas (vrijspraak).

\section{VI.DAFTAR PUSTAKA}

Mardjono Reksodipuro, Hak Azazi Manusia Dalam Sistem Peradilan Pidana, Pusat Pelayanan keadilan dan Pengabdian Hukum, UI, Jakarta, 1994.

Barda Nawawi Arief, Teori - Teori dan Kebijakan Pidana : Alumni, Bandung: 1992, hlm. 197

A.Hamzah dan Irdan Dahlan, Upaya Hukum dalam Perkara Pidana, PT Bina Aksara, Jakarta, 1987.

Harun M. Huzein, Kasasi Sebagai Upaya Hukum, Sinar Grafika, Jakarta, 1992.

R. Soesilo, Hukum Acara Pidana (Prosedur Penyelesaian Perkara Pidana Bagi Penegak Hukum), Penerbit: Politeia, Bogor.1992

Muladi, Demokrasi Hak Asasi Manusia dan Reformasi Hukum di Indonesia, The Habibie Center, Jakarta, 2002.

Muhammad Taufik Makarao dan Suhasril, Hukum Acara Pidana Dalam Teori Dan Praktek, Ghalia, Jakarta, 2004.

Koentjaraningrat, Pengantar Penelitian Hukum, Universitas Indonesia,UI-Pres, Jakarta, 1981.

Setiono, Pemahaman Terhadap Metodologi Penelitian Hukum, UNS Press, Surakarta, 2005.

Soerjono Soekanto, Pengantar Penelitian Hukum, UI Press, Jakarta, 1986.

Soejono Soekamto dan Sri Mamudji, Penelitian Hukum Normatif Suatu Tinjauan Singkat, Grafindo Persada, Jakarta, 2004.

Peter Mahmud Marzuki, Penelitian Hukum, Kencana Prenada Media Group, Jakarta, 2008 
Website : http://yustisia.unmermadiun.ac.id/index.php/yustisia

Muhammad Taufik Makarao dan Suhasril, Hukum Acara Pidana Dalam Teori Dan Praktek, Ghalia, Jakarta, 2004, hlm. 223-226

Djoko Prakoso, Kedudukan Justiabel di Dalam KUHAP, Ghalia, Indonesia, Jakarta, 1985, hlm.270

M. Yahya Harahap (II), Pembebasan Permasalahan Dan Penerapan KUHAP Jilid II, Pustaka Kartini, Jakarta, 1985, hlm. 965

Departemen Kehakiman Republik Indonesia (II), Pedoman Pelaksanaan KUHAP, Jakarta, 1982, hlm.324

Leden Marpaung (II), Proses Penanganan Perkara Pidana (Di Kejaksaan dan Pengadilan Negeri, Upaya Hukum dan Eksekusi), Sinar Grafika, Jakarta, 1992, hlm. 446-447.

M. Yahya Harahap (I), Pembahasan Permasalahan dan Penerapan KUHAP, Pemeriksaan Sidang Pengadilan, Banding dan Peninjauan Kembali, Edisi Kedua, Cetakan Kelima, Penerbit : Sinar Grafika, Jakarta, 2003, Hal 38

Dudu Iswara Machmudin, Pegantar Ilmu Hukum Sebuah Sketsa, PT Refika Aditama, Bandung, 2001, hlm.58. 